\title{
Distribution of Glyphosate- and Thifensulfuron-Resistant Palmer Amaranth (Amaranthus palmeri) in North Carolina
}

\author{
Amy H. Poirier, ${ }^{1}$ Alan C. York, ${ }^{1}$ David L. Jordan, ${ }^{1}$ Aman Chandi, ${ }^{1}$ \\ Wesley J. Everman, ${ }^{1}$ and Jared R. Whitaker ${ }^{2}$ \\ ${ }^{1}$ Department of Crop Science, North Carolina State University, P.O. Box 7620, Raleigh, NC 27695-7620, USA \\ ${ }^{2}$ Department of Crop and Soil Sciences, University of Georgia, P.O. Box 8112, Statesboro, GA 30460, USA \\ Correspondence should be addressed to David L. Jordan; david_jordan@ncsu.edu
}

Received 29 October 2013; Revised 16 December 2013; Accepted 24 December 2013; Published 11 February 2014

Academic Editor: Ioannis Vasilakoglou

Copyright (C) 2014 Amy H. Poirier et al. This is an open access article distributed under the Creative Commons Attribution License, which permits unrestricted use, distribution, and reproduction in any medium, provided the original work is properly cited.

Glyphosate resistance in Palmer amaranth was first confirmed in North Carolina in 2005. A survey that year indicated 17 and $18 \%$ of 290 populations sampled were resistant to glyphosate and thifensulfuron, respectively. During the fall of 2010, 274 predetermined sites in North Carolina were surveyed to determine distribution of Palmer amaranth and to determine if and where resistance to fomesafen, glufosinate, glyphosate, and thifensulfuron occurred. Palmer amaranth was present at 134 sites. When mortality for each biotype was compared to a known susceptible biotype for each herbicide within a rate, 93 and $36 \%$ of biotypes were controlled less by glyphosate $\left(840 \mathrm{~g} \mathrm{ae} \mathrm{ha}^{-1}\right)$ and thifensulfuron $\left(70 \mathrm{~g} \mathrm{ai} \mathrm{ha}^{-1}\right)$, respectively. This approach may have underestimated resistance for segregating populations due to lack of homogeneity of the herbicide resistance trait and its contribution to error variance. When mortality and visible control were combined, $98 \%$ and $97 \%$ of the populations were resistant to glyphosate and the ALS inhibitor thifensulfuron, respectively, and $95 \%$ of the populations expressed multiple resistance to both herbicides. This study confirms that Palmer amaranth is commonly found across the major row crop production regions of North Carolina and that resistance to glyphosate and ALS-inhibiting herbicides is nearly universal. No resistance to fomesafen or glufosinate was observed.

\section{Introduction}

The majority of corn (Zea mays L.), cotton (Gossypium hirsutum L.), and soybean (Glycine max (L.) Merr.) in the United States is currently planted with glyphosate-resistant cultivars or hybrids [1]. Glyphosate has often been applied multiple times during a growing season and for several consecutive years with few other herbicides included [2-4]. This approach, while providing excellent weed control in cotton and soybean in most instances [5-8], has placed unprecedented selection pressure on weed communities and has contributed to a shift to more resistant biotypes [9].

Glyphosate resistance in Palmer amaranth was first confirmed in Georgia in 2005 [10] and later the same year in North Carolina [11, 12]. Levels of resistance varied by population in North Carolina, with some populations requiring over 20 times more glyphosate to reduce shoot fresh weight by $50 \%$ as compared with susceptible populations [12]. Glyphosateresistant Palmer amaranth now occurs in Alabama, Arizona,
Arkansas, Delaware, California, Georgia, Illinois, Louisiana, Michigan, Mississippi, Missouri, New Mexico, North Carolina, Ohio, South Carolina, Tennessee, and Virginia [13, 14].

Palmer amaranth is currently one of the most common and most troublesome weeds in many southern states due to its competitive nature and resistance to multiple herbicides $[15,16]$. A survey was conducted in the fall of 2005 to determine the extent and distribution of glyphosate-resistant Palmer amaranth in North Carolina [12]. Resistance to glyphosate was observed in $17 \%$ of the 295 populations sampled. Additionally, resistance to thifensulfuron was observed in $18 \%$ of the populations.

It is generally accepted that glyphosate-resistant Palmer amaranth has become more common and more widespread since 2005. Determining how distribution of glyphosateresistant Palmer amaranth has changed since 2005 and determining if resistance to other herbicides occurs are important in helping growers and those who advise growers develop 
effective management strategies to control this weed. Furthermore, understanding the extent and distribution of the problem is important for developing recommendations to curb the spread of glyphosate resistance to noninfested regions.

Fomesafen and glufosinate are used to control broadleaf weeds in major agronomic crops in the US and have become effective and widely used alternatives to glyphosate in these crops, especially when glyphosate-resistant weed biotypes are present [17-22]. There is concern that widespread and repeated use of these herbicides could lead to selection for resistance to the modes of action represented by fomesafen and glufosinate. To date, biotypes in North Carolina expressing resistance to these herbicides either do not exist or have not been under sufficient selection pressure to express resistance in fields in North Carolina. Determining if resistance to these herbicides exist will help growers and their advisors employ alternatives to glyphosate and if needed to control biotypes resistant to fomesafen and glufosinate if they occur. Therefore, objectives of this study were (1) to determine the distribution of glyphosate- and thifensulfuron-resistant biotypes of Palmer amaranth in North Carolina compared with the distribution in 2005 and (2) to determine if resistance to fomesafen and glufosinate is present in North Carolina Palmer amaranth populations.

\section{Materials and Methods}

A survey was administered across the Coastal Plain and Piedmont regions of North Carolina during the fall of 2010 using a grid sampling procedure. A map of the state (North Carolina DeLorme Atlas \& Gazetteer, 9th edition, DeLorme Co., Yarmouth, ME) with latitude and longitude marked at increments of 0.1722 degrees and 0.2167 degrees, respectively, was used. Sample points were established at the intersection of each latitude and longitude marking $(19.03 \mathrm{~km}$ by $19.8 \mathrm{~km})$. Sample points falling within urban areas were omitted. A total of 274 predetermined sites were selected (Figure 1). Some sites were in forests, pastures, swamps, or residential areas, and no Palmer amaranth was present. If no Palmer amaranth was found at the predesignated site, an effort was made to survey surrounding areas within a $1.6-\mathrm{km}$ radius.

A total of 134 Palmer amaranth populations were sampled from soybean and cotton fields. Seed heads from 20 or more plants were collected per site and bulked in paper bags. Seed heads were air-dried and hand-threshed, and seeds were stored at $1^{\circ} \mathrm{C}$ until further use. Plants from seeds collected at these sites were grown in excess in a greenhouse in four replicate pots ( 7.5 by $12 \mathrm{~cm}$ by $5 \mathrm{~cm}$ ) per herbicide rate using a commercial growing medium (Metro Mix 200, Scotts-Sierra Horticultural Products Company, Marysville, OH). Plants were thinned to four to five per pot $5 \mathrm{~d}$ after emergence. A known glyphosate-susceptible and a known glyphosate-resistant population were included for comparison in the experiment with glyphosate [12]. Each pot received $25 \mathrm{~mL}$ of a $4.6 \mathrm{~g} \mathrm{~L}^{-1}$ fertilizer solution (Peters Professional Water Soluble 2020-20 Fertilizer, Scotts-Sierra Horticultural Products Co., Marysville, $\mathrm{OH}) 10$ and $20 \mathrm{~d}$ after weed emergence. Pots were watered three times daily using automatic sprinklers. The greenhouse was maintained at $35 \pm 5^{\circ} \mathrm{C}$, and natural

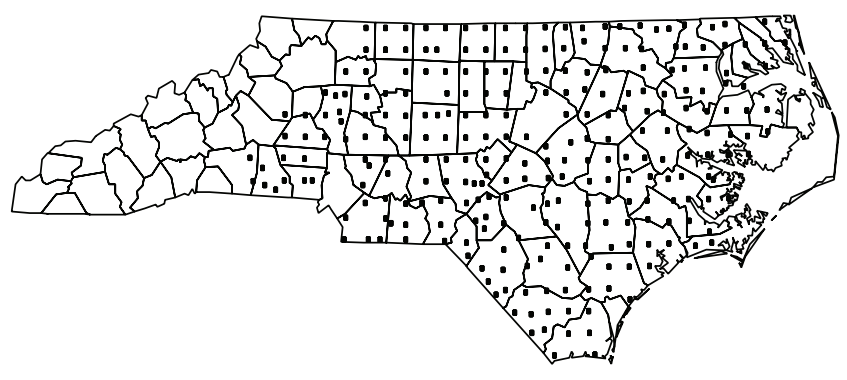

- Sample site

Figure 1: Sample sites for the 2010 survey of North Carolina.

lighting was supplemented for $14 \mathrm{~h}$ daily with metal halide lamps (Hubbell Lighting Inc., Greenville, SC) delivering $400 \mu \mathrm{mol} \mathrm{m}^{-2} \mathrm{~s}^{-1}$.

In separate experiments, Palmer amaranth $10-15 \mathrm{~cm}$ tall was treated with the potassium salt of glyphosate (Roundup WeatherMAX Herbicide, Monsanto Co., St. Louis, MO) at 0 ,

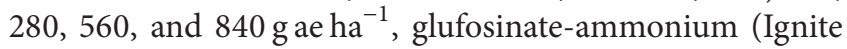
280 Herbicide, Bayer CropScience, Research Triangle Park, $\mathrm{NC}$ ) at $0,410,820$, and $1230 \mathrm{~g} \mathrm{ae} \mathrm{ha}^{-1}$, the sodium salt of fomesafen (Reflex Herbicide, Syngenta Crop Protection, Greensboro, NC) at $0,280,560$, and $840 \mathrm{~g} \mathrm{ae} \mathrm{ha}^{-1}$, and thifensulfuron-methyl (DuPont Harmony SG Herbicide, DuPont Crop Protection, Wilmington, DE) at $0,4.37,17.5$, and $70 \mathrm{~g} \mathrm{ae} \mathrm{ha}^{-1}$. In previous research under similar greenhouse conditions, glyphosate and thifensulfuron at 280 and $4.37 \mathrm{~g} \mathrm{ha}^{-1}$, respectively, were found to control glyphosate-susceptible and thifensulfuron-susceptible Palmer amaranth at least 95\% [12]. In a preliminary experiment, glufosinate at $410 \mathrm{~g} \mathrm{ha}^{-1}$ and fomesafen at $280 \mathrm{~g} \mathrm{ha}^{-1}$ controlled Palmer amaranth at least $95 \%$. The manufacturer's suggested use rates for glyphosate, glufosinate, fomesafen, and thifensulfuron in soybean are $866,450-594,280-420$, and $4.37 \mathrm{~g} \mathrm{ha}^{-1}$, respectively [2326]. Thifensulfuron was selected to represent herbicides that inhibit ALS because it is effective in controlling Palmer amaranth and was used previously by Whitaker [12] as an indicator herbicide in a survey similar to the one presented here. A nonionic surfactant (Induce adjuvant, Helena Chemical Co., Collierville, TN) at $0.25 \%(\mathrm{v} / \mathrm{v})$ was included with fomesafen and thifensulfuron. Herbicides were applied using a $\mathrm{CO}_{2}-$ pressurized backpack sprayer calibrated to deliver $145 \mathrm{~L} \mathrm{ha}^{-1}$ at $275 \mathrm{kPa}$ (glyphosate) or $187 \mathrm{~L} \mathrm{ha}^{-1}$ at $375 \mathrm{kPa}$ (fomesafen, glufosinate, and thifensulfuron) using regular flat-fan nozzles (TeeJet VisiFlo TP 11002 Flat Spray Tips, TeeJet Technologies, Wheaton, IL). Differences in spray volume were based on recommendations by the manufacturers and the goal of optimizing performance for each herbicide. The manufacturer of glyphosate recommends lower spray volumes [23] in part because glyphosate is systemic in plants. Fomesafen and glufosinate are considered contact herbicides with limited translocation. Higher spray volumes are recommended to ensure contact with adequate foliage to control weeds [24, 25]. Thifensulfuron can be applied in a range of spray volumes [26]. Percent visible control according to Frans et al. [27] and 
TABLE 1: Number of Palmer amaranth biotypes controlled at least $90 \%$ by glyphosate and thifensulfuron and the number and percentage of Palmer amaranth biotypes not controlled by the highest rate of glyphosate and thifensulfuron.

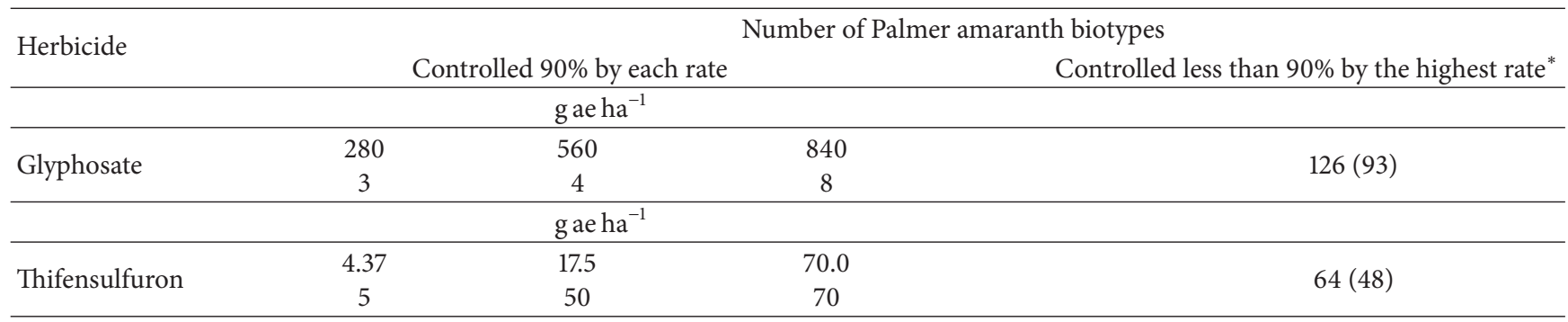

${ }^{*}$ Value in parenthesis represents the percentage of Palmer amaranth biotypes.

the number of surviving plants were recorded $14 \mathrm{~d}$ after fomesafen, glufosinate, and glyphosate application and $28 \mathrm{~d}$ after thifensulfuron application. Percent mortality relative to the nontreated control was calculated. Based on preliminary research, Palmer amaranth control by fomesafen, glufosinate, and glyphosate under greenhouse conditions is readily apparent $14 \mathrm{~d}$ after treatment. Control by thifensulfuron and other ALS-inhibiting herbicides can be slower, and a longer period of time after application is required to assess herbicide efficacy.

The experimental design in the greenhouse was a randomized complete block with four replications and the experiment was repeated once for each herbicide. Data for percent visible control and mortality were subjected to ANOVA by herbicide appropriate for the number of biotypes and herbicide rates excluding the nontreated control. Significance $(P \leq$ 0.05 ) between biotypes and a known herbicide-susceptible biotype was determined using Dunnett's Procedure in SAS (SAS v9.1, SAS Institute Inc., Cary, NC 27513, USA). Because variation from complete control or mortality to no control or survival was noted for individuals within many of the populations, Dunnett's procedure most likely underestimated resistance due to lack of genetic homogeneity associated with herbicide resistance within populations contributing to relatively high error variance. Therefore, biotypes were grouped as susceptible, resistant, or highly resistant according to response to each herbicide and rate of each herbicide. Palmer amaranth was considered susceptible to the herbicides if control was $90 \%$ or greater and mortality $80 \%$ or greater at the low application rate, or if control was $95 \%$ or greater and mortality $90 \%$ or greater at the intermediate rate. Palmer amaranth was considered highly resistant if mortality was $30 \%$ or less at the high application rate. Populations meeting neither of the above criteria were categorized as resistant.

\section{Results and Discussion}

North Carolina is divided into three physiographic regionsthe Mountain region in the western part of the state, the Piedmont Plateau in the central part, and the Coastal Plain in the eastern part [28]. In 2010, 78, 93, 100, 80, 74, and 72\% of the state's corn, cotton, peanut (Arachis hypogaea L.), soybean, tobacco (Nicotiana tabacum L.), and wheat (Triticum aestivum L.), respectively, were grown in the Coastal Plain while $19,7,0,20,23$, and $27 \%$, respectively, were grown in the

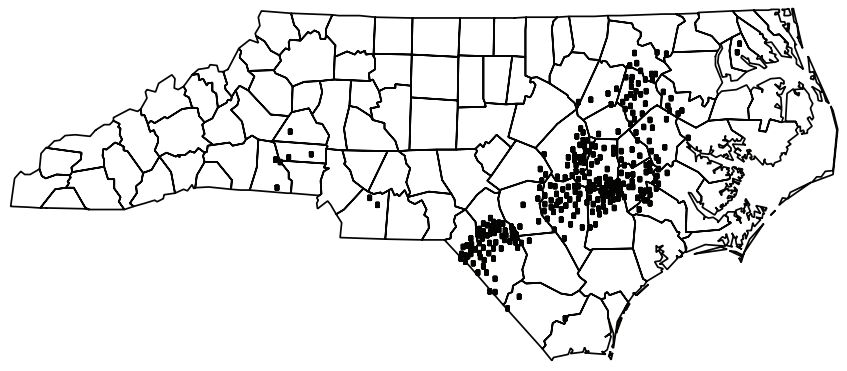

- Locations having Palmer amaranth

FIGURE 2: Distribution of Palmer amaranth in 2005 survey, adapted from Whitaker [12].

Piedmont [29]. Only $3 \%$ of the corn and tobacco and $1 \%$ of the wheat were grown in the Mountain region. This survey, therefore, covered the major agronomic crop production areas of the state (Figure 1).

Palmer amaranth increased its geographical range within the state between 2005 and 2010. Compared to 2005, when Palmer amaranth was most commonly found in the central and southern Coastal Plain (Figure 2), the weed was more readily found in the far eastern and northeastern counties of the Coastal Plain and in the Piedmont in 2010 (Figure 3).

When comparing the number of Palmer amaranth biotypes controlled at least $90 \%$, increasing the rate of each herbicide increased the number of biotypes controlled (Table 1). However, no more than 8 Palmer amaranth biotypes were controlled by glyphosate at $840 \mathrm{~g} \mathrm{ha}^{-1}$ while 70 biotypes were controlled by thifensulfuron at $70 \mathrm{~g} \mathrm{ha}^{-1}$ (Table 1). One hundred twenty-six, or $94 \%$, of Palmer amaranth biotypes were not controlled at least $90 \%$ by the highest rate of glyphosate (Table 1). For thifensulfuron, 64 biotypes, or $48 \%$, of biotypes were not controlled by the highest rate of this herbicide (Table 1).

Mortality and visible control of 95 and $87 \%$ of biotypes, respectively, treated with glyphosate at $840 \mathrm{~g} \mathrm{ha}^{-1}$ differed from a known glyphosate-susceptible biotype using Dunnett's procedure (Table 2). When biotypes were treated with thifensulfuron at $70 \mathrm{~g} \mathrm{ha}^{-1}, 36 \%$ (mortality) and $30 \%$ (visible control) of biotypes differed from the thifensulfuronsusceptible biotype (Table 2). While this approach defines 


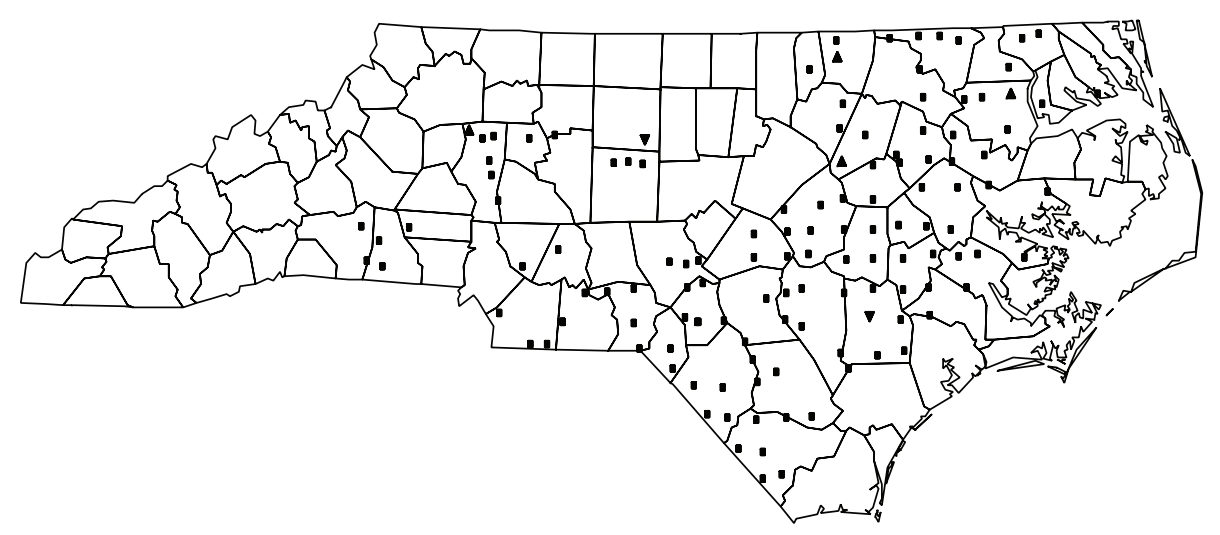

A Glyphosate-resistant, thifensulfuron-susceptible

V Glyphosate-susceptible, thifensulfuron-resistant

- Glyphosate- and thifensulfuron-resistant

Figure 3: Distribution of glyphosate- and thifensulfuron-resistant Palmer amaranth in 2010.

TABLE 2: Percentage of biotypes expressing lower mortality and less visible control than a known susceptible biotype for each rate of glyphosate and thifensulfuron based on Dunnett's Procedure $(P \leq 0.05)$.

\begin{tabular}{|c|c|c|c|c|c|c|c|c|c|}
\hline \multirow{2}{*}{ Herbicide } & \multirow{2}{*}{ Rate $\left(\mathrm{g} \mathrm{ha}^{-1}\right)$} & \multicolumn{4}{|c|}{ Mortality } & \multicolumn{4}{|c|}{ Visible control } \\
\hline & & Percentage of biotypes & $F$ value & $P>F$ & CV (\%) & Percentage of biotypes & $F$ value & $P>F$ & CV (\%) \\
\hline Thifensulfuron & 4.37 & 15 & 2.18 & $\leq 0.0001$ & 95.2 & 25 & 7.73 & $\leq 0.0001$ & 24.6 \\
\hline Thifensulfuron & 17.5 & 30 & 3.00 & $\leq 0.0001$ & 58.8 & 29 & 8.22 & $\leq 0.0001$ & 19.8 \\
\hline Thifensulfuron & 70 & 36 & 5.05 & $\leq 0.0001$ & 52.5 & 30 & 12.54 & $\leq 0.0001$ & 17.7 \\
\hline Glyphosate & 280 & 78 & 6.54 & $\leq 0.0001$ & 85.5 & 60 & 12.39 & $\leq 0.0001$ & 57.8 \\
\hline Glyphosate & 560 & 91 & 7.93 & $\leq 0.0001$ & 92.3 & 76 & 6.74 & $\leq 0.0001$ & 72.5 \\
\hline Glyphosate & 840 & 95 & 11.49 & $\leq 0.0001$ & 95.4 & 87 & 7.91 & $\leq 0.0001$ & 77.3 \\
\hline
\end{tabular}

biotypes that most likely express homogeneity of the herbicide-resistance trait, it most likely underestimates resistance in populations in early stages of resistance expression or those that are segregating. Knowing the frequency of resistance at the initial stages of resistance is important in implementing practices quickly to minimize impact of herbicide resistance on the production system.

To compare the change in frequency of resistance from 2005 to 2010, data from 2010 were assigned to categories similar to those defined by Whitaker [12]. The percentage of the populations resistant to glyphosate increased dramatically during this 5-yr period. Whitaker [12] observed that Palmer amaranth in $17 \%$ of 295 fields sampled in 2005 expressed resistance to glyphosate, and all of these fields were in the central and southern Coastal Plain (Figure 4). In 2010, Palmer amaranth in 128 of the 134 fields sampled, or greater than $98 \%$, was resistant to glyphosate (Figure 3). All plants in the known susceptible biotype were killed completely by glyphosate at the lowest rate (data not shown). No control and no mortality were observed in the known resistant population with either of the lower two glyphosate rates. Only 14\% control and 5\% mortality were observed in the known resistant population with the highest rate of glyphosate (data not shown).

Reported levels of Palmer amaranth resistance to glyphosate have varied among studies [10, 11, 17, 30]. Part of the discrepancy may be due to methodology and the level of susceptibility in the susceptible biotype to which resistant biotypes were compared. Some of the discrepancy is also likely due to varying degrees of homogeneity for resistance in the "resistant" populations. Similar to the survey in 2005 [12], populations in 2010 varied in response to glyphosate. Within some populations, all plants screened were resistant to the highest rate of glyphosate whereas in other populations some plants were killed by the lowest rate and some plants survived the highest rate, suggesting continued segregation of the populations (data not shown). The criterion for the "highly resistant" designation was based upon work by Whitaker [12]. One of the most resistant populations from the 2005 collection had a 20-fold level of resistance based upon $\mathrm{I}_{50}$ values for fresh weight reduction. Fresh weight of that population was reduced about $30 \%$ by glyphosate at $840 \mathrm{~g} \mathrm{ha}^{-1}$ compared with $95 \%$ reduction by glyphosate at $240 \mathrm{~g} \mathrm{ha}^{-1}$ of the same susceptible population as used in the current study. Sixtyseven percent of the nonglyphosate-susceptible populations in 2010 fit into the highly resistant category.

The procedure for collecting biotypes was biased toward finding glyphosate resistance. We did not attempt to determine the herbicide program used in the fields from which seeds were collected. However, with $90 \%$ or more of the cotton and soybean in North Carolina being planted to glyphosate-resistant cultivars [31], there was a high probability that any field from which seeds were collected had been 


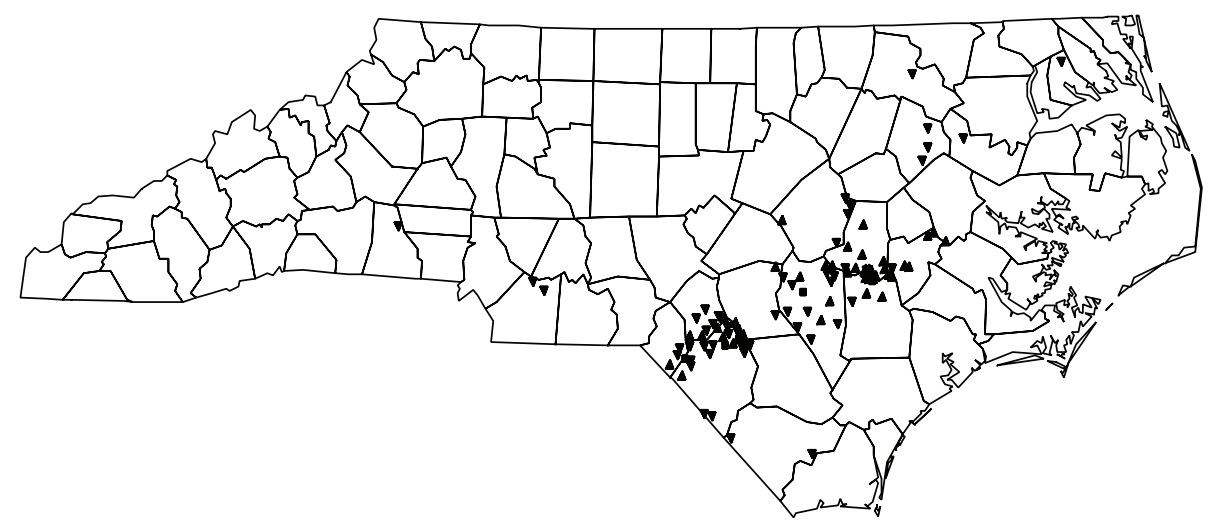

\ Glyphosate-resistant, thifensulfuron-susceptible

$\boldsymbol{\nabla}$ Glyphosate-susceptible, thifensulfuron-resistant

- Glyphosate- and thifensulfuron-resistant

FIGURE 4: Distribution of glyphosate- and thifensulfuron-resistant Palmer amaranth in 2005, adapted from Whitaker [12].

treated with glyphosate, thus increasing the likelihood that Palmer amaranth present was resistant to glyphosate. Nevertheless, the results indicate that glyphosate-resistant biotypes of Palmer amaranth are now very common in the state and that glyphosate-only programs, once highly effective [5-8], will no longer be successful in most of the state's agronomic crop production areas.

Levels of resistance to ALS-inhibiting herbicides vary greatly. Typically, resistant Amaranthus biotypes have very high levels of resistance [32-36]. We arbitrarily designated a population as highly resistant if mortality was $30 \%$ or less at $70 \mathrm{~g} \mathrm{ha}^{-1}$, a rate which is 16 times greater than the manufacturer's suggested use rate for non-STS soybean [26]. Ninetyseven percent of the populations (126 of 134) sampled in 2010 were found to be resistant to thifensulfuron (Figure 3 ). This is compared with only $18 \%$ of the populations exhibiting resistance in 2005 [12]. Among the 2010 populations exhibiting resistance, $17 \%$ were designated as highly resistant (data not shown). Designations of resistant or highly resistant were based upon the average response of the population. Lack of a greater percentage of the populations being designated as highly resistant was the result of continued segregation in the populations at time of collection. In every population, including those designated as susceptible, at least one plant in at least one run of the experiment was not completely killed by thifensulfuron at $70 \mathrm{~g} \mathrm{ha}^{-1}$. Hence, some highly resistant individuals were present in every population. No attempt was made to determine if resistance to other ALS-inhibiting herbicides was present. However, resistance to chlorimuron has been previously confirmed in North Carolina Palmer amaranth [13]. Additionally, Whitaker [12] noted cross-resistance to thifensulfuron, pyrithiobac, and imazethapyr in selected Palmer amaranth populations. Resistance to ALS-inhibiting herbicides is predominately due to alterations of the target site enzyme, and multiple mutations have been identified [37, 38]. Cross-resistance among ALS-inhibiting herbicides is common in Palmer amaranth $[37,39,40]$ and other Amaranthus species $[32,41,42]$.
To further exasperate the problem with managing this weed, 124 (93\%) of the Palmer amaranth populations exhibited multiple resistance to thifensulfuron and glyphosate (Figure 3). This is compared with less than $2 \%$ of the populations collected in 2005 exhibiting multiple resistance (Figure 4). No population was susceptible to both herbicides. Widespread resistance to glyphosate and thifensulfuron (and probably other ALS-inhibiting herbicides) will make controlling Palmer amaranth challenging and will force growers to diversify weed management strategies.

Glufosinate applied postemergence and fomesafen applied preemergence or postemergence control Palmer amaranth [8, 43-48]. Fomesafen can be applied preemergence or postemergence to soybean, and it is currently being widely used in North Carolina soybean. Fomesafen is also widely used in North Carolina cotton as a preemergence treatment. In recent years, glufosinate use in North Carolina cotton has increased rapidly. North Carolina cotton growers in 2013 planted $65 \%$ of their crop to cultivars that allow postemergence application of glufosinate [49], and this was primarily done to control glyphosate-resistant Palmer amaranth. Planting of glufosinate-resistant soybean is expected to increase as more locally adapted cultivars become available. No resistance to either fomesafen or glufosinate was observed among the 2010 populations. Glufosinate at all rates completely controlled all plants in all populations (data not shown). Fomesafen at $840 \mathrm{~g} \mathrm{ha}^{-1}$ completely controlled all plants, and only a few plants were not controlled completely by 280 or $560 \mathrm{~g} \mathrm{ha}^{-1}$ (data not shown). Plants not controlled completely by fomesafen exhibited typical injury symptoms. Although subjective, plant response to fomesafen at the lower rates appeared to be representative of a typical rate response to fomesafen for susceptible plants rather than a reflection of resistance.

Absence of evidence of resistance to fomesafen or glufosinate does not establish that resistant alleles are not present in these populations. Approximately 12,000 plants were screened for resistance to each herbicide when considering 
the number of populations, herbicide rates, number of plants per experimental unit, number of replications, and experiment repetition. Initial frequency of herbicide resistance would be expected to be very low [50], especially given Palmer amaranth control failures with fomesafen or glufosinate associated with possible resistance have not been reported. Initial frequency of resistance is postulated to be several orders of magnitude lower than the number of plants screened in this research [50]. Therefore, herbicide-resistant alleles may be present in these populations but at frequencies below those likely to be detected using this screening procedure.

Collectively, these results document very widespread resistance of Palmer amaranth to glyphosate and thifensulfuron (and most likely other ALS-inhibiting herbicides) in North Carolina. Fortunately, no resistance to fomesafen or glufosinate was detected, but these herbicides are being widely used. The extent of the problem that has developed with glyphosate and thifensulfuron resistance should be ample encouragement for growers to proactively manage to avoid resistance to other herbicide modes of action by using diverse strategies to manage weeds $[51,52]$.

\section{Conflict of Interests}

None of the authors has a conflict of interests in terms of the products mentioned in the paper.

\section{Acknowledgments}

This research was supported by the North Carolina Cotton Producers Association, the North Carolina Soybean Growers Association, and the North Carolina Peanut Growers Association. Rick Seagroves, Jamie Hinton, and Charles Cahoon assisted with sample collection.

\section{References}

[1] M. D. Owen, B. G. Young, D. R. Shaw et al., "Benchmark study on glyphosate-resistant crop systems in the United States. Part 2: perspectives," Pest Management Science, vol. 67, no. 7, pp. 747757, 2011.

[2] S. O. Duke and S. B. Powles, "Glyphosate-resistant weeds and crops," Pest Management Science, vol. 64, no. 4, pp. 317-318, 2008.

[3] S. O. Duke and S. B. Powles, "Glyphosate: a once-in-a-century herbicide," Pest Management Science, vol. 64, no. 4, pp. 319-325, 2008.

[4] C. Foresman and L. Glasgow, "US grower perceptions and experiences with glyphosate-resistant weeds," Pest Management Science, vol. 64, no. 4, pp. 388-391, 2008.

[5] A. S. Culpepper and A. C. York, "Weed management in glyphosate-tolerant cotton," Journal of Cotton Science, vol. 2, no. 4, pp. 174-185, 1998.

[6] A. S. Culpepper and A. C. York, "Weed management and net returns with transgenic, herbicide-resistant, and nontransgenic cotton (Gossypium hirsutum)," Weed Technology, vol. 13, no. 2, pp. 411-420, 1999.

[7] A. S. Culpepper, A. C. York, R. B. Batts, and K. M. Jennings, "Weed management in glufosinate- and glyphosate-resistant soybean (Glycine max)," Weed Technology, vol. 14, no. 1, pp. 77$88,2000$.

[8] J. R. Whitaker, A. C. York, D. L. Jordan, and A. S. Culpepper, "Palmer amaranth (Amaranthus palmeri) control in soybean with glyphosate and conventional herbicide systems," Weed Technology, vol. 24, no. 4, pp. 403-410, 2010.

[9] D. R. Shaw, M. D. Owen, P. M. Dixon et al., "Benchmark study on glyphosate-resistant cropping systems in the United States. Part 1: introduction to 2006-2008," Pest Management Science, vol. 67, no. 7, pp. 741-746, 2011.

[10] A. S. Culpepper, T. L. Grey, W. K. Vencill et al., "Glyphosateresistant Palmer amaranth (Amaranthus palmeri) confirmed in Georgia," Weed Science, vol. 54, no. 4, pp. 620-626, 2006.

[11] A. S. Culpepper, J. R. Whitaker, A. W. MacRae, and A. C. York, "Weed science: distribution of glyphosate-resistant palmer amaranth (Amaranthus palmeri) in Georgia and North Carolina during 2005 and 2006," Journal of Cotton Science, vol. 12, no. 3, pp. 306-310, 2008.

[12] J. R. Whitaker, Distribution, biology, and management of glyphosate-resistant Palmer amaranth in North Carolina [Ph.D. thesis], North Carolina State University, Raleigh, NC, USA, 2009.

[13] I. Heap, "The International Survey of Herbicide Resistant Weeds," http://www.weedscience.org.

[14] R. L. Nichols, J. Bond, A. S. Culpepper et al., "Glyphosateresistant Palmer amaranth (Amaranthus palmeri) spreads in the southern United States (U.S.)," Resistant Pest Management Newsletter, vol. 18, no. 2, pp. 8-10, 2009.

[15] A. S. Culpepper, T. M. Webster, L. M. Sosnoskie, and A. C. York, "Glyphosate-resistant Palmer amaranth in the United States," in Glyphosate Resistance in Crops and Weeds: History, Development, and Management, V. K. Nandula, Ed., pp. 195-212, John Wiley \& Sons, Hoboken, NJ, USA, 2010.

[16] T. M. Webster, "Weed survey-southern states," Proceedings Southern Weed Science Society, vol. 62, pp. 509-524, 2009.

[17] J. K. Norsworthy, G. M. Griffith, R. C. Scott, K. L. Smith, and L. R. Oliver, "Confirmation and control of glyphosate-resistant Palmer amaranth (Amaranthus palmeri) in Arkansas," Weed Technology, vol. 22, no. 1, pp. 108-113, 2008.

[18] L. E. Steckel, C. C. Craig, and R. M. Hayes, "Glyphosate-resistant horseweed (Conyza canadensis) control with glufosinate prior to planting no-till cotton (Gossypium hirsutum)," Weed Technology, vol. 20, no. 4, pp. 1047-1051, 2006.

[19] J. K. Norsworthy, D. Riar, P. Jha, and R. C. Scott, "Confirmation, control, and physiology of glyphosate-resistant giant ragweed (Ambrosia trifida) in Arkansas," Weed Technology, vol. 25, no. 3, pp. 430-435, 2011.

[20] C. W. Cahoon, A. C. York, D. L. Jordan, W. J. Everman, and R. W. Seagroves, "An alternative to multiple protoporphyrinogen oxidase inhibitor applications in no till cotton," Weed Technology, vol. 28, 2014.

[21] L. M. Sosnoskie and A. S. Culpepper, "Changes in cotton weed management practices following the development of glyphosate-resistant Palmer amaranth," in Proceedings of the Beltwide Cotton Conferences, p. 1520, 2012.

[22] D. S. Riar, J. K. Norsworthy, and G. M. Griffith, "Herbicide programs for enhanced glyphosate-resistant and glufosinateresistant cotton (Gossypium hirsutum)," Weed Technology, vol. 25, no. 4, pp. 526-534, 2011.

[23] "Roundup WeatherMAX herbicide label," http://www.cdms .net/LDat/ld5UJ064.pdf.

[24] "Ignite 280 herbicide label," http://www.cdms.net/LDat/ ld7AQ002.pdf. 
[25] "Reflex herbicide label," http://www.cdms.net/LDat/ld6BJ003 .pdf.

[26] "Harmony SG herbicide label," http://www.cdms.net/LDat/ 1d8DC021.pdf.

[27] R. E. Frans, R. Talbert, D. Marx, and H. Crowley, "Experimental design and techniques for measuring and analyzing plant responses to weed control practices," in Research Methods in Weed Science, N. D. Camper, Ed., pp. 29-46, Southern Weed Science Society, Champaign, Ill, USA, 1986.

[28] North Carolina Geological Survey, "Physiographic provinces in North Carolina," http://www.geology.enr.state.nc.us/maps/ GeologicMaps/geomaps.html.

[29] North Carolina Department of Agriculture and Consumer Services, "2012 Agricultural Statistics," http://www.ncagr.gov/stats/ 2012AgStat/AgStat2012.pdf.

[30] L. E. Steckel, C. L. Main, A. T. Ellis, and T. C. Mueller, "Palmer amaranth (Amaranthus palmeri) in Tennessee has low level glyphosate resistance," Weed Technology, vol. 22, no. 1, pp. 119$123,2008$.

[31] United States Department of Agriculture-National Agricultural Statistics Service, "Acreage," http://usda01.library.cornell.edu/ usda/nass/Acre//2010s/2011/Acre-06-30-2011.txt.

[32] M. J. Foes, L. Liu, P. J. Tranel, L. M. Wax, and E. W. Stoller, “A biotype of common waterhemp (Amaranthus rudis) resistant to triazine and ALS herbicides," Weed Science, vol. 46, no. 5, pp. 514-520, 1998.

[33] K. D. Maertens, C. L. Sprague, P. J. Tranel, and R. A. Hines, "Amaranthus hybridus populations resistant to triazine and acetolactate synthase-inhibiting herbicides," Weed Research, vol. 44, no. 1, pp. 21-26, 2004.

[34] W. L. Patzoldt, P. J. Tranel, and A. G. Hager, "A waterhemp (Amaranthus tuberculatus) biotype with multiple resistance across three herbicide sites of action," Weed Science, vol. 53, no. 1, pp. 30-36, 2005.

[35] C. L. Sprague, E. W. Stoller, and L. M. Wax, "Response of an acetolactate synthase (ALS)-resistant biotype of Amaranthus rudis to selected ALS-inhibiting and alternative herbicides," Weed Research, vol. 37, no. 2, pp. 93-101, 1997.

[36] C. L. Sprague, E. W. Stoller, L. M. Wax, and M. J. Horak, "Palmer amaranth (Amaranthus palmeri) and common waterhemp (Amaranthus rudis) resistance to selected ALS-inhibiting herbicides," Weed Science, vol. 45, no. 2, pp. 192-197, 1997.

[37] P. J. Tranel and T. R. Wright, "Resistance of weeds to ALSinhibiting herbicides: what have we learned?" Weed Science, vol. 50, no. 6, pp. 700-712, 2002.

[38] C. M. Whaley, H. P. Wilson, and J. H. Westwood, "ALS resistance in several smooth pigweed (Amaranthus hybridus) biotypes," Weed Science, vol. 54, no. 5, pp. 828-832, 2006.

[39] N. R. Burgos, Y.-I. Kuk, and R. E. Talbert, “Amaranthus palmeri resistance and differential tolerance of Amaranthus palmeri and Amaranthus hybridus to ALS-inhibitor herbicides," Pest Management Science, vol. 57, no. 5, pp. 449-457, 2001.

[40] M. J. Horak and D. E. Peterson, "Biotypes of palmar amaranth (Amaranthus palmeri) and common waterhemp (Amaranthus rudis) are resistant to imazethapyr and thifensulfuron," Weed Technology, vol. 9, no. 1, pp. 192-195, 1995.

[41] M. Sibony, A. Michel, H. U. Haas, B. Rubin, and K. Hurle, "Sulfometuron-resistant Amaranthus retroflexus: cross-resistance and molecular basis for resistance to acetolactate synthaseinhibiting herbicides," Weed Research, vol. 41, no. 6, pp. 509-522, 2001.
[42] C. M. Whaley, H. P. Wilson, and J. H. Westwood, "A new mutation in plant ALS confers resistance to five classes of ALSinhibiting herbicides," Weed Science, vol. 55, no. 2, pp. 83-90, 2007.

[43] J. A. Bond, L. R. Oliver, and D. O. Stephenson IV, "Response of Palmer amaranth (Amaranthus palmeri) accessions to glyphosate, fomesafen, and pyrithiobac," Weed Technology, vol. 20, no. 4, pp. 885-892, 2006.

[44] E. Coetzer, K. Al-Khatib, and D. E. Peterson, "Glufosinate efficacy on Amaranthus species in glufosinate-resistant soybean (Glycine max)," Weed Technology, vol. 16, pp. 326-331, 2002.

[45] J. L. Corbett, S. D. Askew, W. E. Thomas, and J. W. Wilcut, "Weed efficacy evaluations for bromoxynil, glufosinate, glyphosate, pyrithiobac, and sulfosate," Weed Technology, vol. 18, no. 2, pp. 443-453, 2004.

[46] A. S. Culpepper, A. C. York, P. Roberts, and J. R. Whitaker, "Weed control and crop response to glufosinate applied to "PHY 485 WRF” cotton," Weed Technology, vol. 23, no. 3, pp. 356-362, 2009.

[47] J. R. Whitaker, A. C. York, D. L. Jordan, and A. S. Culpepper, "Weed management with glyphosate- and glufosinate-based systems in PHY 485 WRF cotton," Weed Technology, vol. 25, no. 2, pp. 183-191, 2011.

[48] J. R. Whitaker, A. C. York, D. L. Jordan, A. Stanley Culpepper, and L. M. Sosnoskie, "Residual herbicides for palmer amaranth control," Journal of Cotton Science, vol. 15, no. 1, pp. 89-99, 2011.

[49] United States Department of Agriculture-Agricultural Marketing Service, "Cotton varieties planted 2013 crop," http://www .ams.usda.gov/mnreports/cnavar.pdf.

[50] C. Preston and S. B. Powles, "Evolution of herbicide resistance in weeds: initial frequency of target site-based resistance to acetolactate synthase-inhibiting herbicides in Lolium rigidum," Heredity, vol. 88, no. 1, pp. 8-13, 2002.

[51] J. K. Norsworthy, S. M. Ward, D. R. Shaw et al., "Reducing the risks of herbicide resistance: best management practices and recommendations," Weed Science, vol. 60, pp. 31-62, 2012.

[52] D. A. Mortensen, J. F. Egan, B. D. Maxwell, M. R. Ryan, and R. G. Smith, "Navigating a critical juncture for sustainable weed management," BioScience, vol. 62, no. 1, pp. 75-84, 2012. 


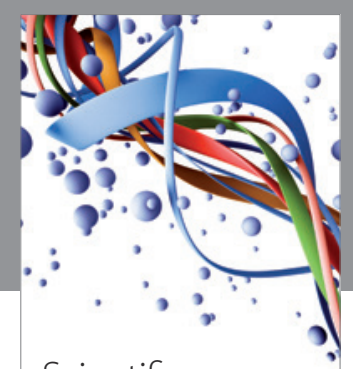

Scientifica
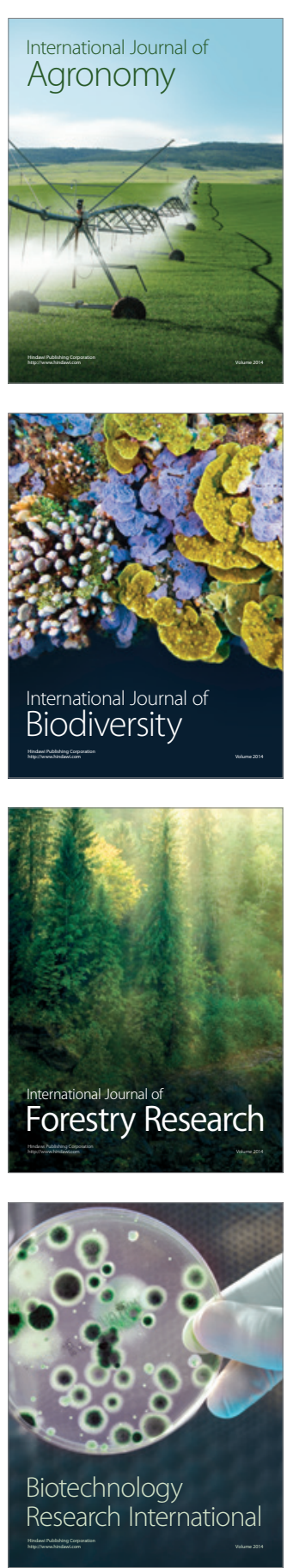
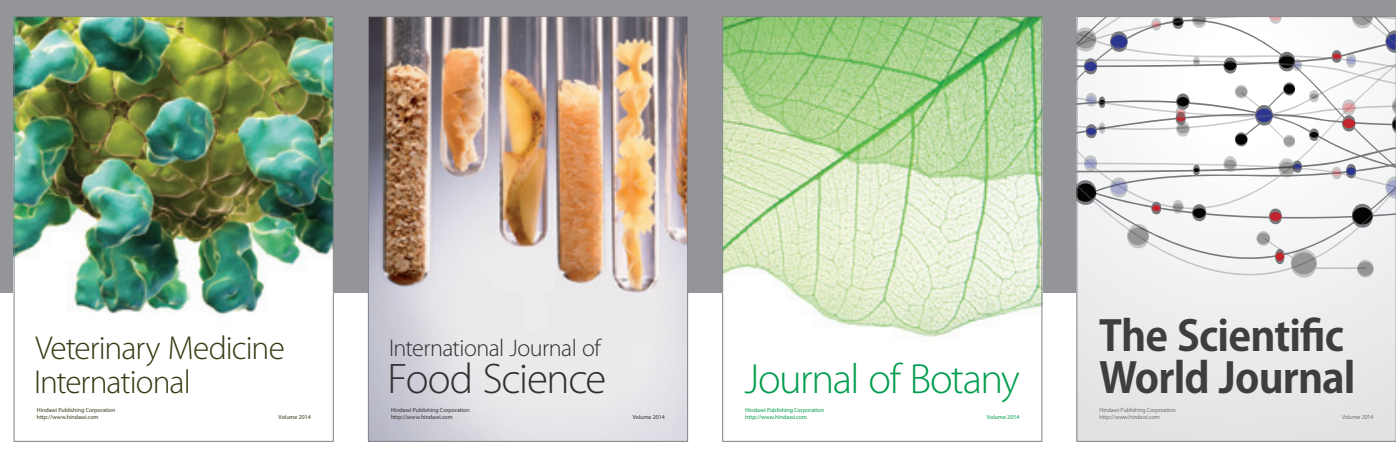

The Scientific World Journal
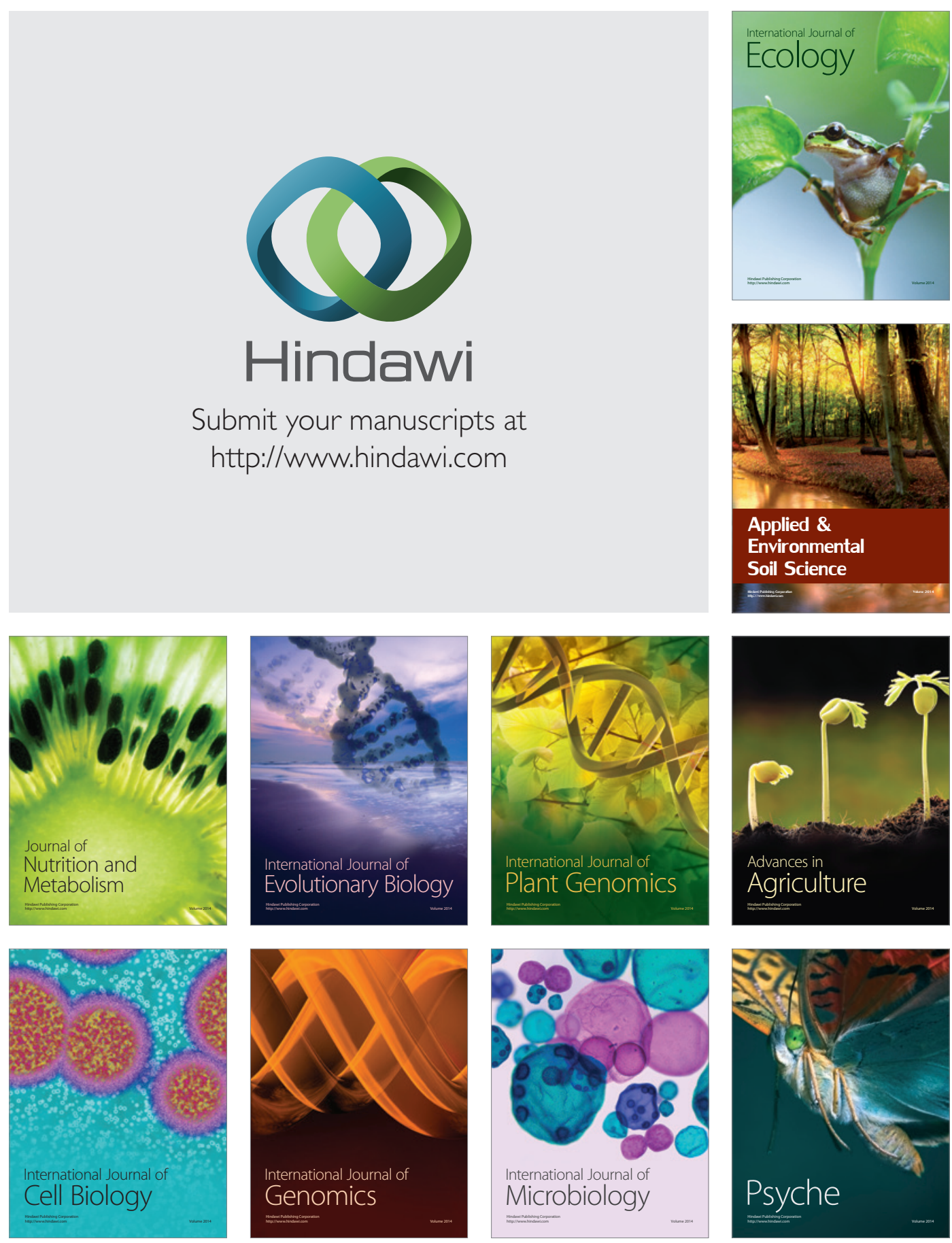